\title{
IT BASED INNOVATION PROCESS AT THE MANAGEMENT MINDSET OF ORGANISATIONS
}

\section{KURUMLARIN YÖNETIM ZIHNIYYETINDE BT TABANLI İNOVASYON SÜRECİ}

\author{
Ahmet EFE 1 \\ ${ }^{1}$ Ankara Kalkınma Ajansı, Turkiye, aefe@ankaraka.org.tr, ORCID: 0000-0002-2691-7517
}

\section{Article Info:}

Received : August 7, 2020

Revised : December 25, 2020

Accepted : December 31, 2020

Keywords:

IT-governance

COBIT-5

innovation

corporate innovation

organizational change management

Anahtar Kelimeler:

BT yönetişimi

COBIT-5

yenilik

kurumsal yenilik

örgütsel değişim yönetimi

DOI: $10.46238 /$ jobda. 777770

\begin{abstract}
In parallel with the increasing global competition based on the management of innovative technology, more people in business functions need to have innovative skills and inevitably be involved in IT processes, decisions and operations. Therefore, as business processes and innovative IT become more interdependent, the need for better integration increases. The inertia and traditional approaches reflected in the mentality of management and governance are considered as one of the main approaches that cause the business processes and IT goals and objectives not to be fulfilled effectively. This study attempts to analyze the need and effects of change in IT governance infrastructures of Development Agencies (DAs), which can be positively developed and encouraged with the COBIT-5 model. This article also reveals the innovation needs of DAs in the management and governance mindset and attempts to demonstrate the applicability of the techniques of the detailed process implementation of the COBIT-5 framework to improve and promote better management and good governance, both in theory and practice.
\end{abstract}

\section{ÖZET}

Yenilikçi teknolojinin yönetimine dayanan küresel rekabetin artması ile paralel bir şekilde işletme fonksiyonları içinde daha fazla insanın yenilikçi becerilere sahip olması ve kaçınılmaz olarak BT süreçlerine, kararlarına ve operasyonlarına dâhil olması gerekmektedir. Bu nedenle, iş süreçleri ve yenilikçi BT birbirine daha fazla bağımlı hale geldikçe daha iyi entegre edilme ihtiyacı artmaktadır. Farklı BT sistemlerinin iş ihtiyaçları ile uyumlu olmaması, yönetim ve yönetişimin zihniyetine yansıyan atalet ve geleneksel yaklaşımların, iş süreçleri ve BT amaç ve hedeflerinin etkin bir şekilde yerine getirilmemesine neden olan başlıca yaklaşımlardan biri olarak kabul edilmektedir. $\mathrm{Bu}$ çalışma, COBIT-5 modeli ile olumlu olarak geliştirilebilecek ve teşvik edilebilecek olan Kalkınma Ajanslarının (DA) BT yönetişim altyapılarındaki değişimin ihtiyacını ve etkilerini analiz etmeye çalışmaktadır. Bu makale aynı zamanda, DA'ların yönetim ve yönetişim zihniyetindeki yenilik ihtiyaçlarını ortaya koymakta ve hem teorik hem de pratik açıdan daha iyi yönetim ve iyi yönetişim düzeyini iyileștirmek ve teșvik etmek için COBIT-5 çerçevesinin detaylı süreç uygulamalarına dair tekniklerinin uygulanabilirliğini ortaya koymaya çalışmaktadır.

\section{1 | INTRODUCTION}

No doubt that today the concept of innovation is one of the most stressed, favored and cited as the most important element of success both for individuals, organizations and countries. The fact of innovation is a prevalent concept innermost of all existence from atoms to cosmos. Although the renewal of body cells of living creatures and compilation and decomposition of atoms in the form of new creations and continuous movement of the globe, moon, sun, other propelling planets and all macro systems had been demonstrating the ever pervasive character of innovation from the beginning of cosmos, it is the fast growing relationships and interactions at the last decade along with rapidly developing cutting-edge technology that have been drastically invoking promotion of perception of innovation the 
importance of which has surged and embossed to be more and more visible during time passed.

In the highly competitive global market, where change and development in every field are accelerated and intensified, institutions need to be renewed by innovation in their products, services and ways of doing business in order to keep up with change and remain competitive.

Bureaucracy, inertia and the sense of security that occur in corporate large organizations sometimes cause these institutions to be disadvantaged in the struggle for innovation. This is why, especially in recent years, companies such as GE, $3 \mathrm{M}$ and Coca Cola, which offer services and products in more traditional sectors, as well as Google and Amazon, which are already innovative, have started to attach great importance to "corporate innovation" and "internal entrepreneurship" studies.

How innovation will be managed is closely related to managers' perspective on innovation. In this context, it can be said that the different perceptions of managers in innovation will affect the way they manage the innovation process. Many factors that affect the innovation performance of businesses are discussed in the literature. For example, information management capacity, IT competency, organizational learning level and cooperation with environmental actors are key elements. However, there are more basic factors that form the background of these factors and affect the successful implementation of innovation. Because these factors that affect innovation performance are a result. It is the characteristics of managers' perception of these factors and their management style that enable them to reach these results effectively. Therefore, it can be said that the main factors affecting innovation performance are the way managers perceive innovation and the way they manage innovation (Taşgit \& Torun, 2016, s. 122).

As a matter of fact, apart from technical and promotional aspects, the innovation in the management mind set is not so much popular though it is of crucial importance in realization of innovative ideas based on freshness and novelty as a requirement of change management in the global competition. This approach of innovation is imperative to be effectively alive and/or continue to survive due to globalization that produced merciless competition, enhanced communications, instant interactions and multidimensional collaborations in a wider area continuously reproducing new strengths, weaknesses, opportunities and threats. That is why innovation becomes not optional but imperative.

It is assumed that the traditional bureaucratic solutions cannot cope with government failures as a result of not keeping up with globally changing environment the regional development agencies
(DAs) in Turkey were founded by Law in 2006 and 26 of which are fully functional with some temporary inconveniencies or inadequate of infrastructure as a result of problems of management and governance requirements.

Presumably, DAs were ascribed to be innovative governmental organizational set-ups that are required to be intermediary at producing synergies and innovation in local and regional domain. In this paper, it is attempted to review the requirements of the innovative concept of management and governance structure of the DAs, the need for business processes re-engineering according to change management process requirements. DAs should try to be adaptive to changing environment by bringing a disciplined and systematic approach to management and governance processes which are in need of innovative management practices.

\section{2 | LITERATURE AND METHOD}

According to the Scholar Database searches on "COBIT" term; it is found that there are 37,000 numbers of studies which is quite large. Similarly, 22,300 found for "Corporate Innovation", 39,400 for "IT Governance" and 58,600 for the "Organizational change management". A complete search for all keywords, it is found 379 articles. Some of the most important studies are being used in our work including some sectoral reports and surveys in order to have a coherent view of both academic and sectoral aspects.

Here we have tried to analyze the applicability of COBIT framework for institutional innovation and change management capability. The answer to the question why COBIT is chosen here is important in understanding of differences of COBIT-5. It is because that it provides more stakeholders a say at the governance and management processes, addresses the increasing dependency on external business and IT parties, deals with the amount of information, which has increased significantly, deals with much more pervasive IT, provides further guidance in the area of innovation and emerging technologies and requires less about audit and more about governance. Since COBIT- 5 is a result of change management at the common body of knowledge which is constantly being revised and reproduced by ISACA according to requirements of the time passing in which approaches, methodologies, terminologies, paradigms and mindsets take sway for a better pace and place in peace.

The paper assumes that the advent of COBIT- 5 is an indication of innovation in change of mindset of management and governance set up of organizations. The main difference for this paper is its special emphasis on the detailed process level of innovation 
and change management which is its sole contribution to the literature.

Bartens et al. (2014) identified characteristics of ebusiness and examine how IT governance frameworks can integrate these characteristics under consideration of a bi-directional business/IT alignment process using COBIT 5 as a benchmark. Shalamanov (2017) attempted to structure the experience as a methodology to support institution building and change management in similar servicebased or technology-oriented organizations. Jeronimo (2018) tried to explain how COBIT5 can help to achieve a higher digital transformation maturity. Khouja et al. (2018) presented a Systematic Literature Review (SLR) on IT Governance in HEIs using a collection of scientific and non-conventional data (grey literature). Jantti and Hotti (2015) tried to propose a framework for IT service governance and a roadmap of IT service management frameworks and standards that can be utilized in establishing IT service governance activities. Merhout and O'Toole (2015) reviewed a prominent IT governance framework, COBIT 5, to determine the extent to which it supports sustainability components, especially as related to the acquisition, use and disposal of IT assets. Efe (2013) proposed COBIT as a model for regional development agencies; integrated wisdom model within COBIT framework (Efe, 2016), studied IT governance applicability (Efe, 2017) and affiliated IT governance with governance pradigms (Efe \& Bengshir, 2019).

According to some surveys, in projects where artificial intelligence (AI), machine learning and other cognitive automation technologies are applied, cloud computing systems provide 20 times faster analysis processing compared to internal systems. Handling hard work on the cloud instead of investing in their own systems provides 45 percent economic savings. In addition, while the time spent by technical specialists decreases by 60 percent, the implementation of new applications falls to hours. 64 percent of respondents said that more IT spending will be made compared to last year. This rate had remained at 46 percent the previous year (Cisco, 2019).

Chief Information Officers (CIOs) are of the opinion that there will be an increase in budgets for new generation solutions such as cloud, big data and mobility that will open the way for innovation. The governments and bureaucracy also do not possess any exemptions in this game because their real success is solely based on their ability to attract new foreign investment and tackle with the deficit of government and capital flows that require continuous navigation of the economy and monitoring for better alignment with the changing business needs and new trends that can change direction of new investments and positive rational expectations based on future perspectives. Therefore innovation in the high-tech and business administration is inevitably reflecting itself into public administration. Results of this movement can be seen in new institutional set-ups, new legislative frameworks and hence policies, tools and strategies of government regulations.

In order to tackle with the speed of innovative tools and techniques, some companies like Cisco has developed AI based innovation. Cisco has announced software innovations designed to make it easier to manage and protect networks. As today's businesses invest more in digital technologies, IT teams are struggling due to the increased workload. To mitigate this burden and enable IT to focus on innovation, Cisco offers new AI and machine learning capabilities that enable IT teams to operate at machine speed and scale thanks to personalized network insights. CISCO is developing innovations that enable more efficient management of users and applications across the entire business network - from campus networks to wide area networks, data centers to the Internet of Things (Cisco, 2019).

Institutions are defined by Douglas, as "humanly devised constraints that structure political, economic and social interaction" (Douglas, 1991, s. 97). Institutions have been seen as the very determinants of individual behavior and attitude of economic agents that contributes significantly to performance of economies by adaptation of innovation and providing innovative ecosystem and creative environment. It is known that the most systematic and disciplined studies started with old institutionalist point of view (from the old institutional economics field-OIE) such as Thorstein Veblen and John Commons, who, from different perspectives, alerted and emphasized the principle role that institutions have played in defining actions of economic agents (Leite, Silva, \& Afonso, 2014).

The institutions are assumed to have an exogenous influence on the economy during years of 1980-2000. Indexes of civil and political liberties developed by Gastil were used by Dawson (1998: 603-619); Gwartney et al. (2006: 255-273). These are several independent pieces of researches in literature. The main driving forces of growth successfully made by the developed countries and challenges of developing countries remain unclear due to the insufficient data as well as different indicators used in various studies. Therefore, many researchers attempted to understand what causes one country to move forward economically and how economic progress add value to institutional development and quality and which institutions are affecting innovation, individual behaviors and economic performance (Dawson, 1998) (Gwartney, Holcombew, \& R., 2006). 
Ha-Joon Chang (2002) has suggested that overcoming the limitations of the neo-liberal discourse on the role of the state via institutions cannot be done by looking for more interventionist models within the neoliberal context, but only by breaking this context and developing an alternative framework that brings institutions and politics to its analytical core. $\mathrm{He}$ proposed calling it institutionalist political economy (IPE) and sketched out how its analyses of the market, the state and politics differ from the ones that are offered by the neo-liberal discourse. However, the institutionalism of IPE seems to go much further than that of New Institutional Economy (NIE) in that it emphasizes the 'temporal priority' of institutions over individual (rather than the temporal priority of individuals over institutions, as it is done in NIE) and that it sees institutions as not simply 'constraining' individual motivations (Chang, 2002) which can sometimes be inputs and outputs of innovation.

In order to share the vision within the organization, the organization should have a well-defined vision, the organization's goals and objectives are coordinated between all departments, and all departments are integrated to meet the needs of the target market depend on employees' awareness of what is wanted to be achieved, adherence to organizational goals, acceptance of organizational vision among all departments, and employees acting as assistants to each other (Nasution, Hanny N. et al., 2010).

Communication between individuals forms the basis of the innovation process. Communication between individuals or groups is often important for the emergence of new ideas. For this, the organizational structure should be designed to encourage employees in the use of acquired or created information (Gold, et al. 2001; Çakar \& Yıldız, 2010), and share marketrelated information (Nasution, Hanny N. et al., 2010).

Sarros et al. (2008) expresses organizational culture as the mediating variable between leadership and innovation. He also argues that organizational culture has an important place in the innovation strategies of the business.

The organizational culture that supports innovation includes elements such as the adoption of uncertainty in order to gain superiority, being open to external influences and surprises that will shake the existing balances and stability, and even encourage them. It is possible to give a premium to untested methods, those who are not known to be successful, mechanisms, rules, behaviors and relationships whose results cannot be fully predicted. In this context, the strategy of gaining advantage by differentiation comes to the fore (Işıklı et al., 2010).

For customer focus, it is necessary to fulfill the factors that give importance to after-sales services, that the objectives of the business are aimed at customer satisfaction, understanding customer needs and continuously evaluating the service and operating strategies are aimed at increasing customer value (Rhee, J. et al., 2010).

Among the elements of the organizational culture that support innovation, it is extremely important to be rival-oriented. Studies on this subject systematically analyze competitors' products, sales, etc. It shows that the information about the innovation positively affects the innovation (Cillo et al., 2010).

\section{INNOVATION MANAGEMENT AND DEVELOP- MENT AGENCIES (DA) AS INNOVATIVE INSTITUTIONS}

Accelerating competition beyond the quality and the existence of goods or services has made innovation the most important competitive factor for organizations aiming for growth. Within the new trade and industrial order based on innovation, each institution makes an initiative in this direction and foresees to maintain its place in the market or to grow in today's world, where the speed of change is dramatically increasing.

Especially, it is not easy to catch this expansion for institutions that only do repetitive business or link business growth to a main industry. The uncertainty behind innovation is that it goes hand in hand with R\&D definitions and business structure, it requires creativity, it can be influenced by different sectors, it is developed based on cooperation rather than in closed laboratories, etc. factors have opened the door to new learning for all institutions.

Based on the basic thoughts that innovation can be realized with creativity, suggestions are made that it is not possible to manage innovation properly. Innovation refers to both innovation and the process of realizing innovation. In institutional structures, repeatable innovation should be targeted instead of one-off and random successes. In line with this goal, creating the necessary climate by providing a tolerant business environment to creativity and innovative identities should be the first priority of organizations. Innovation is not a one-step incremental activity; on the contrary, it is a continuous activity that affects the whole organization with internal and external factors in a way that seizes opportunities and increases market share. For this reason, companies that establish a system that encourages and manages innovation have the opportunity to develop, produce and market their products and services with superior features. Since the keywords of innovation are change and innovation, the most important problem in the innovation management process is to manage change. The main components 
of change management are people, business processes and technology.

Technology management covers all technologies owned by the company, including those that are purchased, licensed and acquired through collaborations. It includes functions to identify and coordinate technology-based competitive advantage. It aims to develop and maintain the company's technological competitiveness. It is not only about new technologies, but also about the strategic use of existing technologies. R\&D Innovation Management includes the following points:

- It includes all types of innovation (technological, organizational, marketing).

- Scientific, technological and administrative processes are all covered.

- It must control the processes that run throughout the organization.

- It is essential to manage different and nonrecurrent processes.

- It focuses on dealing with resistance to innovation within the company and in the market.

It also requires the resolution of behavioral problems. Innovation is closely correlated governance of knowledge management at the local level which is the fact of diffusing tacit knowledge of innovation amongst region, localization of technology supporting supplier development by assisting local companies, universities and research enterprises to develop their technological capabilities, and recollecting entrepreneurial knowledge in the form of wisdom for the cause of local development and common good for which conventional public organizational structure and traditional central bureaucracy could not effectively and efficiently serve.

Figure 1. Organizational Structure of DAs

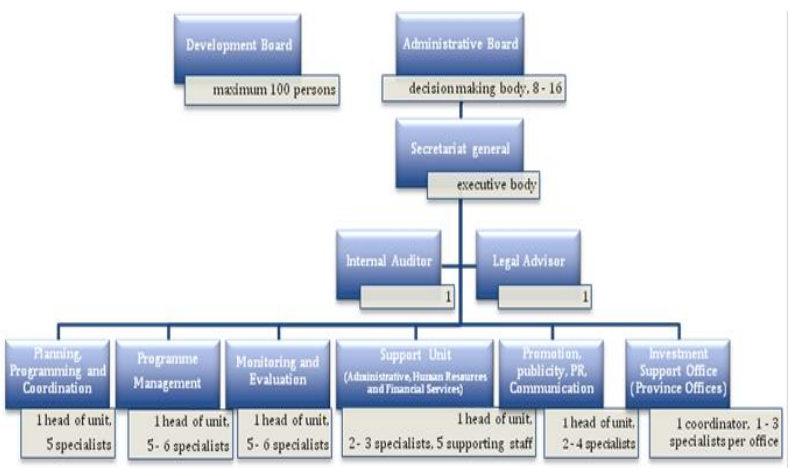

The governance structure of DAs and their working principles, procedures and organizational topology demonstrate an innovative novel nature in comparison with other traditional governmental organizations.

\section{4 | INNOVATION AS PADARIGM SHIFH IN IT GOVERNANCE MINDSET}

According to Meyer and Garg (2005), innovation is the successful development of a new technology or a new combination of existing technologies economically to create a significant change in the value / price offered to the user. Innovation must start with a user. Technology and innovation are not the same. Innovation is the result of a new technology or new combinations of existing technologies. Company employees and managers knowing the sources of innovation will increase the efforts related to innovation (Dodgson, 2008, s. 70-80).

According to the theory of "paradigm shift" which was developed by Thomas KUHN, (Kuhn T. , 1962, s. 10) the scientific advancements are not evolutionary, but rather a "series of peaceful interludes punctuated by intellectually violent revolutions", and in those revolutions "one conceptual world view is replaced by another". Kuhn said that "awareness is prerequisite to all acceptable changes of theory (Kuhn: 1962: 67) that all begins in the mind of human beings according to what is perceived, if normal or abnormal, consciously or unconsciously. That is why we have chosen the "mindset" which is crucial in the innovation process as a paradigm shift.

Figure 2. Governance of Enterprise IT

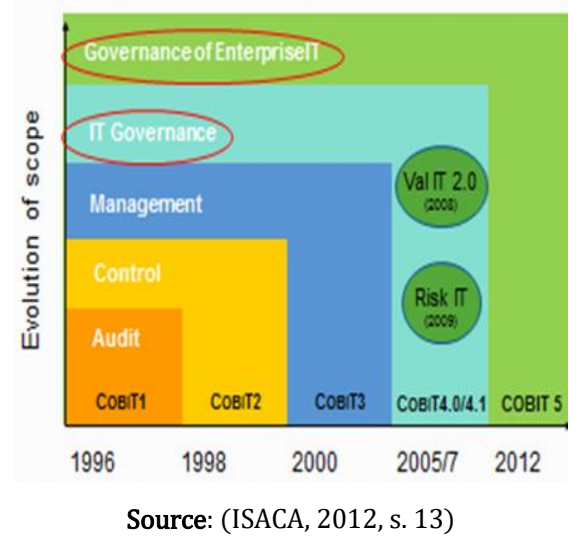

The changes are reflected in the COBIT development life cycle can be seen as results of paradigm shifts triggered by changing environment as the time passed from 1996 to 2012 in which period both a paradigmatic shift and different but incrementing conceptual approaches are seen as innovative such as audit, control, management, IT Governance and Governance of EnterpriseIT.

Innovation-oriented activities in businesses are shaped within the framework of managers' innovation perceptions and innovation management styles. These activities continue from the creation of ideas to commercialization. As a result, while some 
innovation efforts are groundbreaking, some innovation efforts fail. At this point, the concept that differentiates businesses and shows their innovation ability levels is innovation performance. COBIT provides metrics for performance measurement of innovation related processes. Innovation performance is expressed as the commercial dimension in the return of new products, processes and ideas to the business. While the innovation performance measurements of the enterprises show the outputs of the previous innovation activities, they can be seen as a prerequisite for the implementation of new innovation activities. In this respect, innovation performance indicators will enable businesses to understand their current situation in an innovative way, whether successful or unsuccessful. In addition, with the determination of the innovation performance of the business, it will be revealed what the innovation performance may be affected by (internal and external organizational environmental factors) and what should be done to increase the performance. Therefore, management and governance of innovation processes can be well established and measured according to COBIT Process Assessment Model.

\section{5 | BASIC PRINCIPLES OF COBIT-5}

COBIT-5 is founded on 5 key principles for governance and management of enterprise IT. These principles bring a systematic approach to tackle with organizational capacity building in the changing environment as a priori to innovative management mindset.

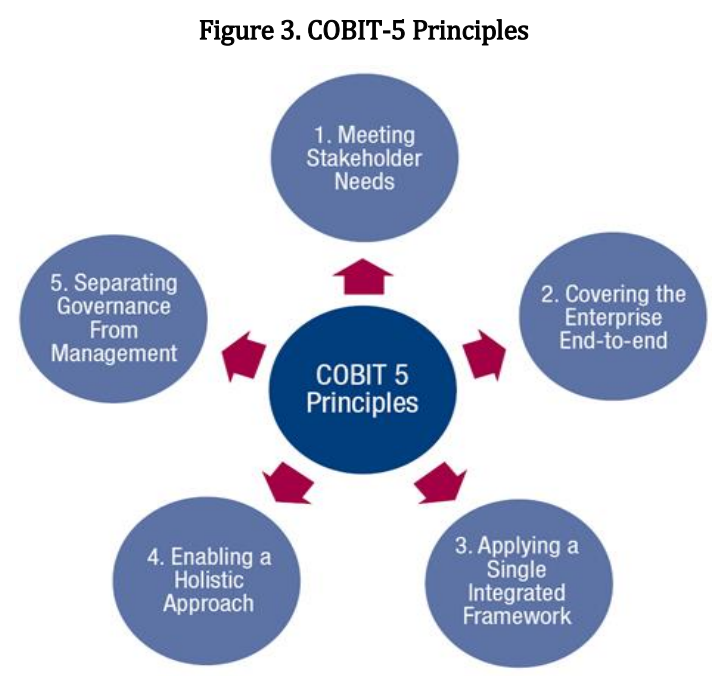

Source: (ISACA, 2012, s. 13)

Basic principles that COBIT-5 has put forward can be discussed briefly as such:

\section{1 | Meeting Stakeholder Needs}

This principle in the management mindset gives an organizational vision of raison d'etre which has to exist for each organization no matter how much complicated or public-private.

Compliance with the strategy should be taken into account in both collecting and evaluating innovative ideas. By using mechanisms such as Competition and Campaign in corporate innovation management products, DA can direct internal and external stakeholders in regional innovation ecosystem to generate ideas and experiment in areas that are important / urgent for the organization.

Thinking that innovation is not only "new product" or "new technology", DA can organize contests and campaigns for different topics such as "entering new markets", "increasing efficiency", "creating new business models" and "excelling in resource efficiency".

As public bodies at regional level, the DAs exist to produce value for stakeholders at local level by making a sustainable balance between the realization of benefits and optimization of risk and of resource usages.

Figure 4: Relationship of stakeholder needs with GEIT and adding value.

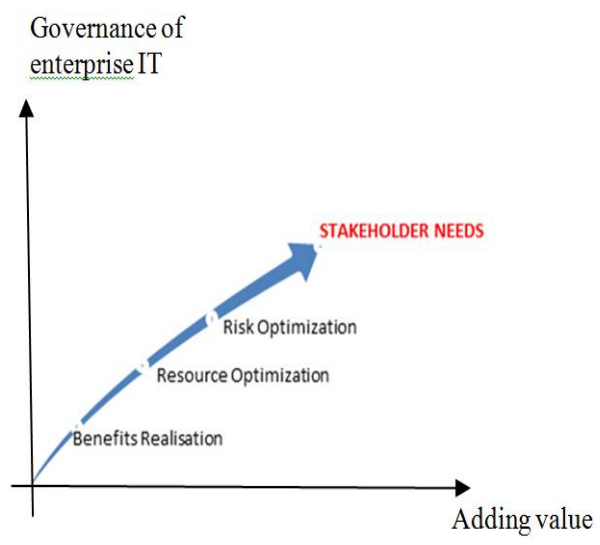

Source: EFE: COBIT-5:2013:7

As is shown in the figure above, all stakeholders need adding value which can be provided by means of benefits realization, risk optimization and resource optimization clauses as the governance of enterprise IT level increases. Development Council of DA is a consultative body established to "enhance the cooperation among public institutions, private sector, non-governmental organizations, universities and local governments in the region and to direct/guide the agency" (Art. 8 of the Law 5449). The Development Council consists of 100 representatives of the provinces. These include public sector representatives, civil society and private sector representatives. The Decrees on Establishment provide detailed number of representations from each region.

Stakeholder needs have to be translated into actionable stages both at regional plans and support programs developed by DAs. Despite of the fact that 
the needs of stakeholders are included in the structure of DAs at the conceptual stage satisfactorily however, the implementations that provide definitions, analysis and management of needs of stakeholders are missing to the extent that DAs are meeting with development board just once a year since it is a requirement of the Act 'Law on Establishment and Duties of Development Agencies" (TBMM, 2006b)(Law No. 5449, published in the National Gazette on 08.02.2006).

\section{2 | Covering the Enterprise End-to-End}

Apart from staff members of DAs every person from development boards or administrative board should be included in the knowledge and change management of DAs.

\section{3 | Applying a Single, Integrated Framework}

Single and integrated framework will be efficient in KPIs measurements and metrics. Developing and benefiting from innovations, especially radical / disruptive innovations, is a long-term effort. Therefore, it would be misleading to measure "business results" only. Besides business results, it would be useful to measure innovation processes (how many ideas were collected, how many people participated, how long it took from idea to prototype, etc.). For the case of DAs, since there is no any prescribed framework by Law to be implemented DAs have the capacity to choose and initiate whatever framework seems to be fitting to their needs.

\section{4| Enabling a Holistic Approach}

Seven categories of enablers are very broadly defined as anything that may help achieve the objectives of DAs such as triggering local potentialities of all sectors, enhancing knowledge accumulation and alleviation of administrative procedures that are needed for investment initiations etc.

\section{5 | Separating Governance from Management}

In the case of DAs the management also manages, report and monitor the processes of governance on behalf of the boards since the governance actors do not possess any permanent and unique separate office or staff.
Figure 5: Governance and Management Key Areas

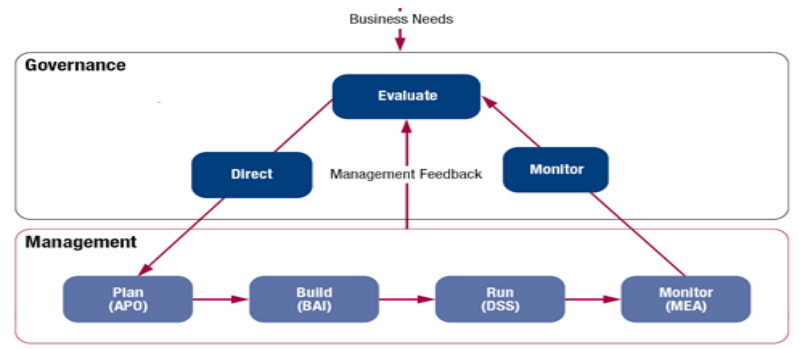

Source: (ISACA, COBIT 5: A Business Framework for the Governance and Management of Enterprise IT., 2012, s. 32)

The governance structure is run by development board and administrative board while technical management is processed by office of secretary general, internal departments and investment support offices. According to regulations and related Law, under the process of "Plan" depicted above in the figure-5, the content aspects of regional plans and corporate strategic plans are being provided by governance mechanism while technical aspect of regional plans and corporate strategic plans such as design, coordination and publication are provided by management at the case of DAs. Therefore, at this point there is a contradiction between COBIT-5 principle and implementation of DAs.

\section{6 | MAIN ENABLERS OF COBIT-5}

The COBIT-5 framework defines seven categories of the enablers:

Figure 6: COBIT-5 Enablers

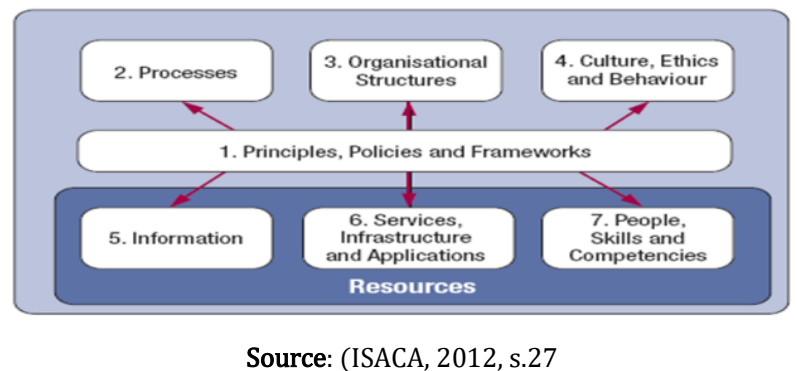

6.1 | Principles, policies and frameworks

As was mentioned above the framework or any standard is missing for DAs and while principles and policies are provided by Ministry of Science and Technology as a one size fits all approach which does not comply with this enabler requirement.

\section{2 | Processes}

COBIT-5 defines a process that solely dedicated to Manage Innovation (AP004). At the book for enabling processes (ISACA, Enabling Processes, 2012, s. 69) this AP004 process is described as;

- To maintain an awareness of information technology and related service trends, identify 
innovation opportunities, and plan how to benefit from innovation in relation to business needs,

- To analyze what opportunities for business innovation or improvement can be created by emerging technologies, services or IT-enabled business innovation, as well as through existing established technologies and by business and IT process innovation.

- To influence strategic planning and enterprise architecture decisions

Process Purpose Statement of Manage Innovation (AP004) is to achieve competitive advantage, business innovation, and improved operational effectiveness and efficiency by exploiting information technology developments. This process is divided into 6 sub-processes.

Figure 7. Innovation management sub-processes

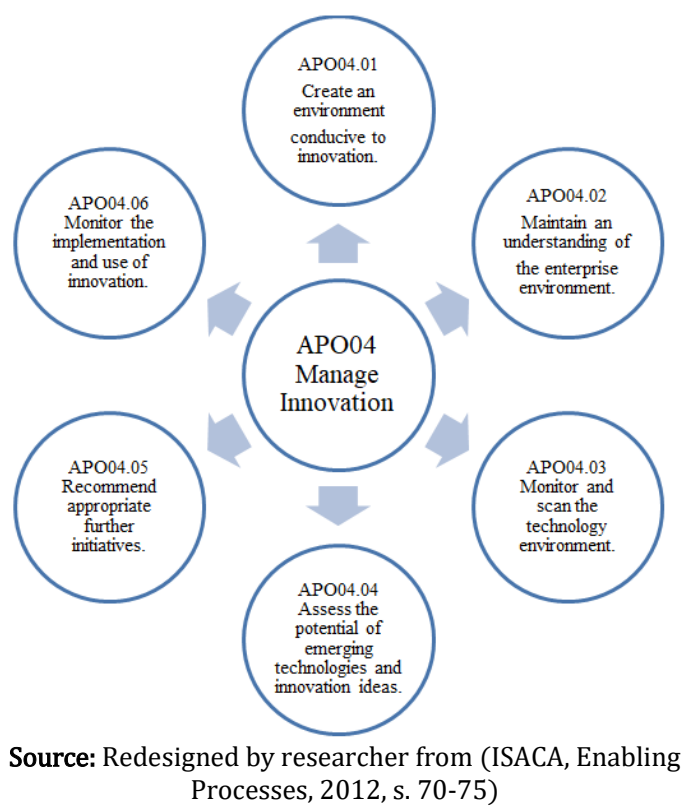

As is seen at RACI chart $^{1}$ of the process, different roles have to be defined for each sub-process. The definition of process innovation may seem unnecessary compared to others, but in terms of corporate and institutional innovation, it is like butter to bread. People in many large firms are surrounded by internal processes that make it easier for their firms to operate on a flat and legal basis. These are middle management, human resources, accounting, finance, senior management and similar employees. They are often aware of processes that are not working well and have an idea of how they can work more effectively. Of course they are sometimes wrong, but they are more right. Their ideas increase productivity and help the firm save.

${ }^{1} \mathrm{RACI}$ Chart is a technique to demonstrate different roles Responsible, Accountable, Consulted and Informed at each process.
Process innovation and innovation management require application of RACI charts to all processes.

COBIT-5 defines process goals, IT related goals and also specific activities for each process that are to be executed according to RACI chart given above. RACI Matrix is one of the methodologies used in 6 Sigma project management and is a requirement of COBIT process management. However, many institutions where 6 Sigma or COBIT is not applied use this methodology effectively in determining the job descriptions of the employees and determining the roles / responsibilities / authorities.

It is very important to create, document and implement well designed efficient processes in all process-oriented applications. However, in order for a process to function well, the roles of people in each step of the process must be clearly defined. The RACI matrix is an application created for this purpose, defining the responsibilities, roles and information flow of the people in the processes.

Responsible (R) - Performs the work

The 'Responsible' role is assigned to the person who actually performs the task or activity. The person performing that activity may not be (A) Accountable; however, in some cases, Responsible (R) and Accountable (A) roles may be assigned to the same person depending on the nature and importance of the job.

Accountable (A) - Principal liable

Accountable is the person or role that has the ultimate liability for a specific task. Only one role / person is accountable for any task. This role cannot be delegated to other person or persons.

(C) Consulted - Provides input

It may be the person (s) who need information or consult in order to perform a task. Assigning more than one (C) Consulted role for a task may risk delaying the completion of that job.

(I) Informed - Information Flow

In order to ensure a healthy flow of information, people who need to be informed should be identified after the task is completed. Failure to determine this role correctly can lead to miscommunication and delays. 


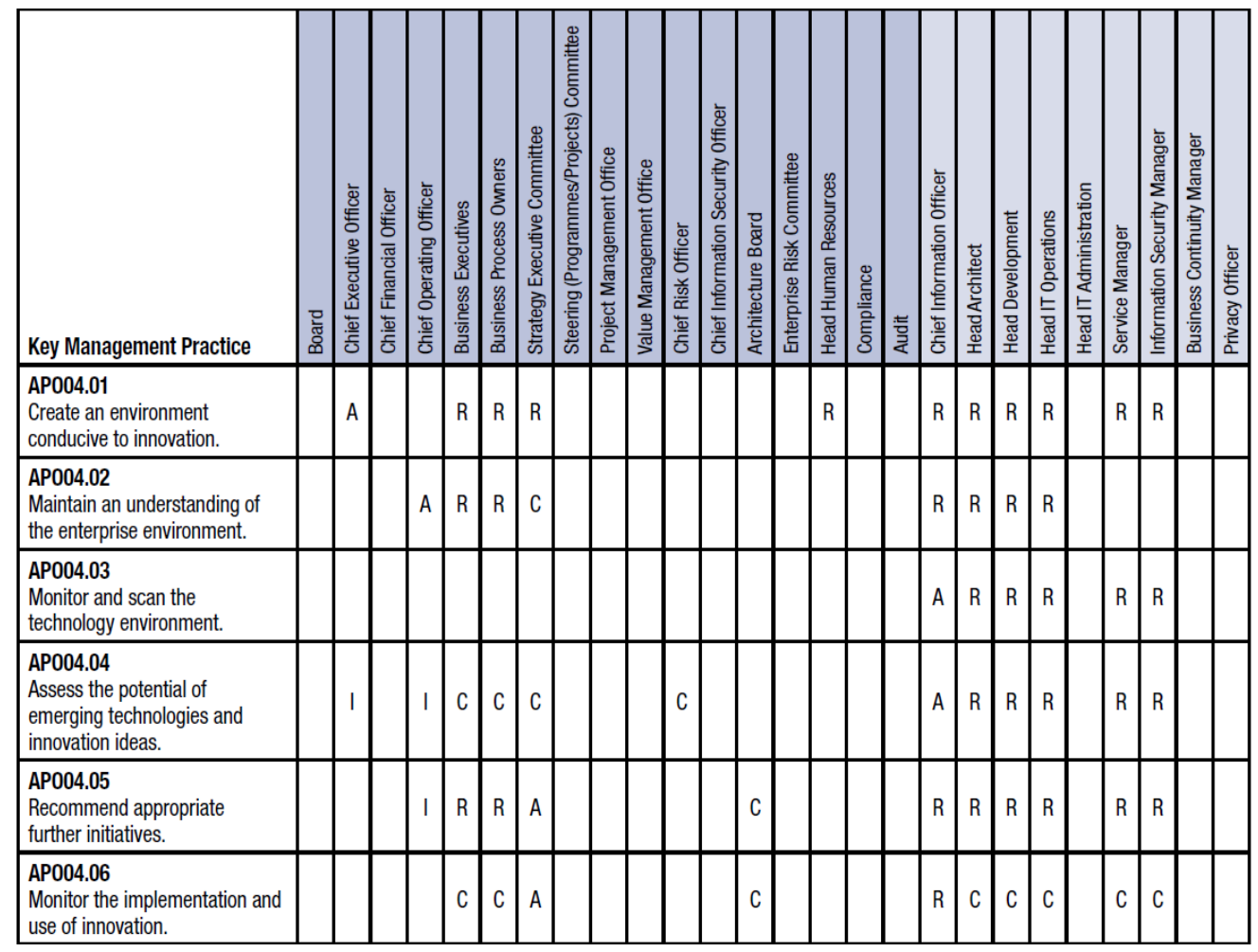

Source: (ISACA, Enabling Processes, 2012, s. 70)

\section{3 | Organizational structures}

Organizations need to change their organizational structures when they grow in business volume or when they introduce new products and services. The managers of the organization often think that as the volume increases, they can create different units by dividing the works into smaller parts and keeping the organizational structure under better control. Most of the time, a new structure is tested by seeing that the changes made are insufficient to achieve the expected results.

However, the fact that a known real organization can be competitive is not only different from the products and services, but also depends on factors such as customer loyalty, efficiency and cost advantage. To achieve this, organizations strive to develop their own strategies and put them into practice. For this, they need innovative organizational structures that can realize these strategies, achieve their goals, and create efficiency and cost advantages, as much as they need to develop correct and distinctive strategies.

Organizational structuring should not aim to respond to growth in terms of volumes or products / services, but should aim at achieving the goals of the organization. Organizational structuring depends on the basic competencies of the organization, the processes that will make the promised value proposition, and its cultural structure. None of these ingredients can be ignored.
As a result, DAs need to review existing organizational structures according to result oriented programs (SOP) and determine the most suitable structure for them. Establishing the right vision and goals, increasing the value offered to the entrepreneurs and investors, the correct restructuring of business processes, development of human capital, intellectual capital and corporate capital will increase the competitiveness dynamics of DA region. The organizational structure of DAs should undergo a redefinition of roles and responsibilities in order provide a basis for effective segregation of management and governance functions and processes.

\section{4 | Culture, ethics and behavior}

Although there are many studies trying to reveal the determinants of the organizational culture that supports innovation, where organizational culture and innovation are interrelated, there is no consensus on what the determinants of the organizational culture that support innovation are (Aksel, 2010).

The ability of a society to produce innovations depends on its cultural structure. Managing innovation is about creating a culture where new ideas are generated, valued and supported. In any case, companies need to change their culture and develop their innovation culture to improve their innovation capabilities. 
Organizational culture is formed and developed under the leadership. It can create the innovation culture by realizing the structure, strategy and cultural changes that will transform the organizational culture for the innovation culture of the leaders.

\section{5 | Information}

One of the biggest contributions of COBIT 5 to the domain of information governance and management is the information goals, which are quality criteria based on development and revisions of former versions of COBIT information criteria. This innovative development is neither philosophical nor theoretical, but rather a technical aspect of intrinsic, contextual and security/accessibility information goals/criteria that can be applied to all enablers by practitioners who need reasonable and applicable paradigm and contextual definitions (Efe, 2016)

Moreover, there is growing stakeholder need in the use of data, information, knowledge and wisdom in enterprise contexts in order to survive in competition, surpass rivals and excel in reproduction of innovative products that can be considered under the governance goal of the value optimization concept of COBIT 5 (Efe, 2016)

\section{6 | Services, infrastructure and applications}

DAs should have required resources to provide services, infrastructure and other applications by insourcing or outsourcing.

\section{7 | People, skills and competencies}

Innovative ideas can come from policies, principles or just one person, but building a successful product or service out of the idea is a task that a multi-functional (or multi-disciplinary) team can do. In order to work on the ideas chosen for DA, principles and policies should enable teams of 7-10 people from different disciplines such as design; manufacturing, purchasing, marketing, and industrial design should be formed. DA should enable individual or group suggestions to be opened to discussion and contribution of wider masses with the comment and voting mechanisms it provides in both suggestion / campaign and competition modules regarding regional development planning and programming.

\section{7 | CONCLUSION}

Innovation is undoubtedly one of the most studied topics in recent years, both in business and management literature. Businesses want to gain competitive advantage in an innovative way to seize market superiority and researchers are exploring how this can be achieved, managed and disseminated. It has been stated throughout the study that there are many determinant factors affecting innovation.
Innovation is the double-headed sledgehammer of risk management. It is both a defense against threats and a breakthrough for opportunities. It is a huge weapon that serves all the purposes of risk management. Innovation is the only way to build tomorrow from today, to prepare breathes of fresh air at the summits from today. It is the mortar of the resistance to be gained against the changing economic and political environment. It is the name of automated action against risks. It is not possible for a company or institution to innovate if it does not connect innovative thinking to its culture and strategic movement as an arterial. Innovation requires investment. Resources are needed to invest for successful IT based innovation. It is essential to be in contact with the local government, development agencies, universities and associations to find resources and to work in a convincing discipline of financial companies.

In fact, the only thing that prevents institutions from showing their innovative potential is actually a few people who are ahead of the creative process. Changing the corporate culture without the support of the whole institution is something that few innovative leaders can achieve. Often, innovative leaders' skills are limited because it is impossible for them to express their opinions. By focusing on features that will undermine innovative development, you can identify the barriers that you will face and create a world where your organization's existing leaders, managers and employees can shine in an innovative nature. Measurement and Evaluation is useful not only to identify innovative leaders, but also to see who is more likely to undermine the creative process.

Here, it is understood that success depends on the integration of the innovation activity with the corporate strategy of the organization. Employees at all levels should be able to take on new roles with great responsibilities; teams come together to collaborate rather than groups with limited relationships; a more efficient and effective environment is to be created.

For a DA to successfully manage innovation, it is essential to have knowledge, experience and the ability to use them specific to regional dynamics and potentialities:

- DA innovation strategy should constitute the most important part of corporate strategy. The primary objective of this strategy is to collect regionally and locallyspecific data and information.

- DA innovation strategy must be shaped in a way that allows key stakeholders to cope with the rapidly changing complex external environment, enabling DA to evaluate current and expected developments in 
technology, threats and market circumstances.

- Internal structures and processes must balance potentially conflicting requirements. Here, DA aim should be to ensure the identification and development of special information in technological fields and to use this information and technical know how in technological fields, potential business areas and product groups of national and local priorities.

Successful management of innovation takes place through a continuous learning process. To accelerate and make the learning process more effective:

- $\quad$ DA should establish mechanisms for sharing experience and discussing successes as well as failures within regional context.

- DA staff should learn and apply tools and techniques developed for innovation management such as COBIT process modelling.

- DA should develop different approaches in innovation management with simple experiments that fits regional needs.

- DA should analyze and review how to manage innovation right now to meet regional stakeholder's needs.

In addition to the above, the use of benchmarking techniques also contributes to success in innovation management. On the other hand, benchmarking is a technique that allows the current performance of DA to be systematically examined and demonstrated. From this point of view, it is not necessary to make a comparison with an organization similar to yours.

For Innovation Management there should be a structured process, key activities, key indicators and RACI Charts for each process. According to COBIT framework, the "AP004 Manage Innovation" process requires implementation of 5 different sub processes as follows:

- AP004.01: Create an environment conducive to innovation.

- AP004.02: Maintain an understanding of the enterprise environment.

- AP004.03: Monitor and scan the technology environment.

- AP004.04 Assess the potential of emerging technologies and innovation ideas.

- AP004.05: Recommend appropriate further initiatives.

- AP004.06: Monitor the implementation and use of innovation.
COBIT-5 seems to be able to promote the level of the service required for DAs via integration with KAYS which is an MIS system for development projects and programs required for effectiveness and efficiency of KAYS.

Implementing COBIT-5 is not only based on the management decision making but also devotion and commitment that require paradigm shifts from traditional management to post-modern proactive management that is a comprehensive organizational, procedural, structural business and IT alignment. 


\section{REFERENCES}

Aksel, I. (2010). İșletmelerde İnovasyon Ve İnovasyonu Destekleyen Örgüt Kültürünün Belirleyicileri Ve Bir Araştırma. İstanbul: İstanbul Üniversitesi SBE Basılmamış Doktora Tezi,http://nek.istanbul.edu.tr:4444/ekos/TEZ/4 8618.pdf.

Bartens Y., Schulte F. and Voß S., (2014) "E-Business IT Governance Revisited: An Attempt towards Outlining a Novel Bi-directional Business/IT Alignment in COBIT5," 47th Hawaii International Conference on System Sciences, Waikoloa, HI, 4356-4365,doi: 10.1109/HICSS.2014.538

Chang, H.-J. (2002). Breaking the mould: an institutionalist political economy alternative to the neo-liberal theory of the market and the state. Cambridge Journal of Economics, 539-559.

Cillo, P.; Luca L.M. ve Troilo, G., (2010), "Market information approaches, product innovativeness, and firm performance: An empirical study in the fashion industry", Research Policy, 39, pp. 12421252

Cisco. (2019). Cisco'dan yapay zeka ve makine öğrenimi temelli inovasyon. Retrieved 08 08, 2020, from https://www.cisco.com/c/tr_tr/about/press/20 19/250619.html

Çakar, N. D. ve Yıldız S., (2010), "Bilgi Yönetimi Ve Örgütsel Etkinlik İlişsisi: Örgüt Kültürü Ve Örgüt Yapısının Temel Etkileri”, Ege Akademik Bakış, 10 (1), 71-93

Dawson, J. (1998). Institutions, investment, and growth: New cross-country and panel data evidence. Economic Inquiry Vol. XXXVI, October , 603-619.

Dodgson, M. G. (2008). The Management of Technological Innovation Strategy and Practice. New York: Oxford University

Douglas, N. (1991). Institutions,. the Journal of Economic Perspectives, Vol. 5, No. 1, http://links.jstor.org/sici?sici=08953309\%28199124\%295\%3A1\%3C97\%3AI\%3E2. 0.CO\%3B2-W, pp. 97-112.

Efe, A. (2013). Cobit-5 Framework as a Model for the Regional Development Agencies in Turkey. ICEBEG (s. 33-42). İzmir: International Journal of Ebusiness And Egovernment Studies.

Efe, A. (2016). Unearthing and Enhancing Intelligence and Wisdom Within the COBIT 5 Governance of Information Model. Cobit Focus, 1-15.

Efe, A. (2017). Kamu yönetiminde COBIT-5 bilișim yönetişiminin kalkınma ajansları özelinde uygulanabilirliği. Yönetim Bilişim Sistemleri Dergisi , 2(1) , 1-26.

Efe, A , Kaya Bensghir, T . (2019). Innovatıon In The Governance Paradigm from It Governance To Good Enough Governance. Yönetim Bilişim Sistemleri Dergisi , 5 (1) , 3151.https://dergipark.org.tr/tr/pub/ybs/issue/50 $489 / 617589$.

Gold, H.A., Malhotra, A.,ve Segars, A.H,. (2001), "Knowledge Management: An Organizational Capabilities Perspective", Journal of Management Information Systems,18: 185-214.

Gwartney, J., Holcombew, R., \& R., L. (2006). Institutions and the Impact of Investment on Growth, . Blackwell Publishing Ltd., KYKLOS, Vol. 59 - - No. 2, 255-273.

ISACA. (2012). COBIT 5: A Business Framework for the Governance and Management of Enterprise IT. Rolling Meadows, IL: ISACA.

ISACA. (2012a). Enabling Processes. USA: ISACA.

ISACA. (2012b). COBIT 5 Implementation. . Rolling Meadows, IL: ISACA.

Işıklı, G.; FerecZade, A. ve Taşçığlu H. (2010), "Türk İşletmelerinde Örgüt Kültürü ve İnovatif Faaliyetler", Journal of Azerbaijani Studies, Vol. 13, No. 2

Jäntti, M., Hotti, V. (2016) Defining the relationships between IT service management and IT service governance. Inf Technol Manag 17, 141-150. https://doi.org/10.1007/s10799-015-0239-z.

Jeronimo, A.C.S, (2018) IT governance in digital transformation : a COBIT 5 overview according idc maturityscape, Dissertation as requirement for obtaining the Master's degree in Information Management,

http://hdl.handle.net/10362/56923 IT Governance in Higher Education Institutions: A Systematic Literature Review

Khouja M., Bouassida I. Ben Halima Y., Moalla S. (2018) IT Governance in Higher Education Institutions: A Systematic Literature Review, International Journal of Human Capital and Information Technology Professionals (IJHCITP) 9(2) DOI: 10.4018/IJHCITP.2018040104

Kuhn, T. (1962). the structure of scientific revoluiton. Chicago, USA: University of Chicago.

Leite, D. N., Silva, S. T., \& Afonso, O. (2014). Institutions, Economics And The Development Quest. Journal of Economic Surveys, 491-515.

Merhout, J. and O'Toole, J. (2015) "Enhancing the Control Objectives for Information and Related 
Technologies (COBIT 5) Framework for Sustainable IT Governance," Journal of the Midwest Association for Information Systems (JMWAIS): Vol. 1 : Iss. 2 , Article

Meyer, A. D., \& Garg, S. (2005). Inspire to Innovate Management and. New York: Palgrave Macmillan.

Nasution, Hanny N. at al., (2010), "Entrepreneurship: Its relationship with market orientation and learning orientation and as antecedents to innovation and customer value", Industrial Marketing Management, Article in press

Rhee, J.; Park, T. ve Lee D., (2010), "Drivers of innovativeness and performance for innovative SMEs in South Korea:Mediation of learning orientation", Technovation, 30, pp. 65-75

Sarros, J. C.; Cooper, B.K. ve Santora, J. C. (2008), "Building a Climate for Innovation Through Transformational Leadership and Organizational Culture", Journal of Leadership \& Organizational Studies, 15, ss. 145-158

Shalamanov, V., (2017) İnstitution Building for IT Governance and Management, Journal of Information and Security, vol.38, 13-34, https://doi.org/10.11610/isij.3801

Taşgit, Y. E., \& Torun, B. (2016). Yöneticilerin İnovasyon Algısı, İnovasyon Sürecini Yönetme Tarzı ve İşletmelerin İnovasyon Performansı Arasındaki İlişkiler. Journal of Administrative Sciences, Volume: 14, Sayı / N: 28,, pp.: 121-156.

TBMM. (2006b). Kalkınma Ajanslarının Kuruluşu, Koordinasyonu ve Görevleri Hakkında 5449 sayılı Kanun. Retrieved from www.mevzuat.gov.tr: http://www.mevzuat.gov.tr/Metin1.Aspx?Mevzu atKod $=1.5 .5449 \&$ Mevzuatlliski $=0 \&$ sourceXmlSe $\operatorname{arch}=\&$ Tur $=1 \&$ Tertip $=5 \&$ No $=5449$ 